\title{
Museum Customer Experience and Virtual Reality: H.BOSCH Exhibition Case Study
}

\author{
Filomena Izzo \\ Economics Department, University of Campania “Luigi Vanvitelli”, Capua, Italy \\ Email: filomena.izzo@unicampania.it
}

How to cite this paper: Izzo, F. (2017) Museum Customer Experience and Virtual Reality: H.BOSCH Exhibition Case Study. Modern Economy, 8, 531-536.

https://doi.org/10.4236/me.2017.84040

Received: March 5, 2017

Accepted: April 14, 2017

Published: April 17, 2017

Copyright $\odot 2017$ by author and Scientific Research Publishing Inc. This work is licensed under the Creative Commons Attribution International License (CC BY 4.0).

http://creativecommons.org/licenses/by/4.0/

\begin{abstract}
The article tries to investigate the effects of virtual reality application on customer experience in museum. A case study was applied in order to analyze the research question. The author finds that virtual reality may provide a valuable experience with customers as well as cultural management. Data have been collected only at "Palazzo Ducale" in Venice (Italy), which provide a limited overview of the topic; however a comparative analysis might be applied to evaluate the phenomenon in other Country. Virtual reality is a quite new topic. Only few scholar have been analyzed this phenomenon in relation to museum. The aim of this study is to enrich the current literature review and provide some recommendations to public and private practitioners (professionals), providing a diverse prospective of the virtual reality and also strategical actions to improve customers' experience.
\end{abstract}

\section{Keywords}

Virtual Reality, Museum, Experiential Marketing, Palazzo Ducale, H.BOSCH Exhibition

\section{Introduction}

The information and the communication technology (ICT) is opportunity for museums, which can leverage these technologies to "break free" and improve accessibility and communication of its collections and exhibitions, establishing a more intense dialogue with the visitor [1]-[6]. ICT enables the expansion of the customer base, complementing traditional cultural institutions in the performance of their educational duties and learning, through new forms of active and participatory learning by the community. The present study is focused on a single technology application: Virtual Reality (VR). VR is a computer generated three-dimensional environment in which the subject or the subjects interact with each other and with the environment as if they were really in it; it is immersive 
when it is able to create a sense of absorption and "immersion" in digital environment.

The use of a technological application, more or less sophisticated, to assist the process of a museum visit experience can represent one of the basic elements of a differentiation strategy. This is fundamental in the current context where competition between cultural institutions and the growing alternative use of free time, has increasing levels of intensity.

Museums could increase their competitive advantage over their direct competitors by improving the quality of the visiting experience. Moreover, this choice can be of strategic importance with respect to reputation, in order to improve museum attractiveness, and more general, its ability to relate to its stakeholders.

Obviously, a satisfied visitor can share the experience with other users, thereby increasing the visibility of the museum and its "social" rating. Also, the visitor is more likely to establish a long-lasting relationship with the museum, continuing beyond the visit through a digital connection. In other words, the museum can activate loyalty with its audience and this is one of the prerequisites for the development of the museum's marketing strategy.

A recent survey on strategies implemented in major museums worldwide with regard to the digitization process, the use of these instruments and reassessment of web sites carried out by Axiell in 2016 for the Museums and the Web's Conference, shows that the use of integrated ICT applications had a significant impact on the public: $48 \%$ of the museums has had an increase in physical visits, $50 \%$ saw an increase in the number of visits to their website and $82.3 \%$ of the museums has recorded an increase of social media sites visitors.

In summary, the digital communication is important for cultural institutions as it allows them to: 1) convey additional information support, which is potentially unlimited, not only in the form of text or images, but also in the form of video or audio files; 2 ) provide information (for example, view the details of a work) that are not otherwise available; 3 ) customize the visitor experience through the possibilities which the user selects among the information content of its interest (level of detail, format, available time, staff training, etc.); 4) access to the collections of the cultural institution before, during or after the visit.

This, obviously, has various positive effects for cultural institution: first, ICT applications improve visiting experiences and the overall enjoyment of user experience; second, they allow to collect data on the visitor's behavior; third, they determine a greater cultural institution attraction to younger visitors; fourth, they encourage the cultural institution to enable partnerships with private enterprises; finally, they allow specific categories of users to visit.

Visitors too will get a number of advantages arising from the use of these technologies: first, they may access additional information supports in an automatic way, even through their mobile device (BYOD); second, they can benefit from new learning contexts (real/digital world), which exceed the traditional visit model (passive use) and increase its level of involvement; third, they can de- 
termine more easily and with greater autonomy how to use the time available within the cultural institution (what to see, what to know, where to go); finally, they can live the visiting experience in a more funny way, associating culture with the image of dynamism and modernity. We may conclude that: the artists create the stories, cultural institutions tell them and technology makes them accessible.

The paper is organized as follow: in Section 2 the theory on experiential marketing in museums is discussed leading to the case study. In Section 3 the methodology is outlined. This is by following Sections 4 and 5 where the result, discussion and conclusion are presented.

\section{Theoretical Framework}

Museum visitors are interested in variety experiences, more complex, responding to a mix of expected benefits [7]-[18]. Art, education, leisure, tourism and entertainment, has considerable influence on the consumption of cultural goods [19]. The economic business value or specifically enterprise culture, is increasingly linked to the ability to engage user/customer [20]. Pine and Gilmore worked out a framework that highlights experience different forms depending on the level of participation of the visitor and the type of relationship and connection that is established between the client and the event. Customer participation can be divided into active and passive, while the type of relationship that is established with the environment can be divided into absorption or immersion.

In present research, the experiential consumption in museum is positioned in education stem from the interaction between absorption and active participation, the approach is based on the combination of education and entertainment, known as edutainment. The edutainment is based on analyzing visiting experience in relation to service provided by technological tools that set up an interactive and active visit. Based on previous consideration the research question was: What is the influence of the museum digital strategy on visitors experience and satisfaction?

\section{Methodology}

This study is the result of a research collaboration undertaken with the App Trippercompany (apptripper.org) and the "Fondazione Musei Civici di Venezia".

The article reports the case study of BOSCH exhibition, VR immersive experience, implemented by Palazzo Ducale in Venice. The exhibition is inspired by the work of Bosch "Four Visions Afterlife", in which visitors can immerse themselves in afterlife world imagined by the great artist five centuries ago. Such application will be enriched by a series of original visual and sound experiences that will project visitors into the fantastic world of the afterlife.

The virtual reality movie involves visitors at the end of the exhibition path. In order to answer the research question (What is the influence of the museum digital strategy on visitors experience and satisfaction?) the study adopted qualitative and quantitative approach. 
Questionnaire designed by us with App Tripper Company and "FondazioneMusei Civici di Venezia". The parties analyzed in the questionnaire were:

1) the reasons for the use of technological tools,

2) the level of satisfaction with the adequacy of the information provided,

3) the propensity to repeat the use of information system based on VR technology,

4) finally, a comprehensive assessment of the system used was requested.

There are no questions on socio-demographic information and on familiarity of technological tools, in accordance with the project's knowledge objective (testing museum VR technology application and the evaluation of its effectiveness) a short questionnaire was made in order to assess the level of satisfaction with the initiative.

Quantitative study (survey data collection and analysis) were collected with App Tripper Company and "Fondazione Musei Civici di Venezia". We worked on 3000 surveys, collected from February 19 to 1 March 2017. The exhibition period is from February 19 to June 4, 2017, then the collected data are not the final ones; but the initial results are very positive, so, certainly, they will be better during "tourist high season" (it will start in May).

\section{Results}

App Tripper company and Fondazione Musei Civici di Venezia created the application of VR at Palazzo Ducale in Venice. VR immersive experience is inspired by the work of Bosch "Four Visions Afterlife", in which visitors can immerse themselves in afterlife world imagined by the great artist five centuries ago. Such application will be enriched by a series of original visual and sound experiences that will project visitors into the fantastic world of the afterlife.

Actually, there are $2 \mathrm{VR}$ workstations, the virtual tour takes 4 minutes, visitors interviewed (using VR application) are on average 300 per day.

The results of the interviews are very positive: the level of satisfaction with the adequacy of the information provided is high; moreover, there is high propensity to repeat the use of information system based on VR technology; finally, interviews give an excellent rating on overall experience. At last the principal reason to use of VR technological is the curiosity, demonstrating, so, some feeling of visitors with ICT application.

Based on the success of the initiative, the museum manager decided to increase VR work stations (up to four) by the end of March. Moreover in May, with the start of the "high tourist season", the stations will be eight.

\section{Discussion and Conclusions}

The use of a technological application, more or less sophisticated, to assist the process of a museum visit experience can represent one of the basic elements of a differentiation strategy. This is fundamental in the current context where competition between cultural institutions and the growing alternative use of free time, has increasing levels of intensity. 
Museums could increase their competitive advantage over their direct competitors by improving the quality of the visiting experience. Moreover, this choice can be of strategic importance with respect to reputation, in order to improve museum attractiveness, and more general, its ability to relate to its stakeholders.

The study results show the importance of creating a museum kit that can entertain and educate at the same time (edutainment), making the exhibition space not just containers of objects, but places of entertainment, in which, through a more entrepreneurial approach than in the past, can be achieved fruitful contamination between the cultural sector and the commercial one; combining expertise ranging from historians to marketing experts and multimedia designers.

A "knowledge integration" that becomes crucial to implement new approach of management of cultural heritage, which means: marketing, culture, knowledge, entertainment, personalization, satisfaction.

Museums presented a variety of audiences in constant evolution, regarding to which is necessary to identify correct and appropriate ways for dialogue, declining languages and tools of mediation in keeping the objectives of knowledge dissemination that is given. Museums, to be able to communicate in an appropriate way, must first know how to listen to all their users, even (or especially) those of a younger age, who often are not attracted by history and art but generally fans of technology, which-if appropriately involved-could ultimately relate to its future visitors.

The main limitation of the present study is attributable to the fact that the results cannot be extended because the data have been collected only at "Palazzo Ducale", which provide a limited overview of the topic; however a comparative analysis might be applied to evaluate the phenomenon in other Country.

Cultural heritage exists to communicate to visitors or, better said, it lives if it can effectively communicate the knowledge produced over time, as one of its main functions is its contribution to the cultural development of society. Communication, therefore, is an instrumental action for the generation and spreading of knowledge to visitors and, among those, to tourists. We may conclude that: the artists create the stories, cultural institutions tell them and technology makes them accessible.

\section{References}

[1] Cataldo, L. and Paraventi, M. (2007) Il museo oggi. Linee guida per una museologia contemporanea. Hoepli, Milano.

[2] Hazan, S. (2011) The Museum in the Palm of Your Hand: Presenting the Israel Museum through ICT. Il Capitale Culturale, 3, 11-23.

[3] Solima L. (2014) Digital Resources and Approaches adopted by User-Centred Museums: The Growing Impact of the Internet and Social Media. In: Aiello, L., Ed., Management of Cultural Products. E-Relationship Marketing and Accessibility Perspective, IGI Global, London, 181-199.

[4] Izzo, F., Mustilli, M. and Guida, M. (2015) Realtà aumentata e valorizzazione dei beni culturali. Riflessioni sull'offerta culturale casertana. Proceedings of Sinergie 
Annual Conference, Termoli, 9-10 July 2015, 797-809.

[5] Izzo, F., Mustilli, M., Sasso, P. and Solima, L. (2016) Service Orientation and Technology Innovation in Museum: Museo Archeologico Nazionale of Naples Case Study. Proceedings of 26th Annual RESER Conference, Naples, 8-10 September, 879-888.

[6] Izzo, F., Mustilli, M., Sasso, P. and Solima, L. (2016) Smart Tourism Destination from IOT Perspective: Adaptive Orientation System. Proceedings of 6 th International Conference on Tourism (ICOT), Naples, 29 June-2 July 2016, 654-666.

[7] Spranzi, A. (2001) L'innovazione nel marketing dell'arte: Un caso paradigmatico di economia dell'innovazione. Sinergie Rapporti di Ricerca, 11.

[8] Troilo, G. (2002) Postmodernità, consumo e marketing dei beni artistici e culturali. Micro e Macro Marketing, 11, 9-32.

[9] Goulding, C. (2002) The Museum Environment and the Visitor Experience. European Journal of Marketing, 34, 261-278. https://doi.org/10.1108/03090560010311849

[10] Severino, F. (2005) Un marketing per la cultura. FrancoAngeli, Milano.

[11] Granelli, A. and Traclò, F. (2006) Innovazione e cultura. Come le tecnologie digitali potenzieranno la rendita del nostro patrimonio culturale. Il Sole 24 ore, Milano.

[12] Tallon, L. and Walker, K. (2008) Digital Technologies and the Museum Experience: Handle Guides and Other Media. Altamira Press, London.

[13] Carù, A., Cova, B. and Maltese, L. (2008) Un approccio duale al marketing esperienziale: Divertimento e approfondimento nell'immersione. Mercati e Competitività, 4, 17-40.

[14] Failla, A. and Immirzi, E. (2008) 3D e mondi virtuali. Beni culturali e nuove modelli di fruizione. Galassia Web. La cultura nella Rete. Giunti Editore, Firenze.

[15] Golinelli, M.G. (2012) Patrimonio culturale e creazione di valore. Cedam, Padova.

[16] Gilli, G. and Rozzi, F.M. (2013) Smart museum: La psicologia della fruizione artistica. Franco Angeli, Milano.

[17] Cerquetti, M. (2014) Marketing museale e creazione di valore: Strategie per l'innovazione dei musei italiani. Franco Angeli, Milano.

[18] Collodi, D., Crisci, F. and Moretti, A. (2015) Consumer Behaviour nei prodotti artistici: prospettive di ricerca. Proceedings of IV Congresso Internazionale ItaliaFrancia. Le Tendenze del Marketing, Paris, 21-22 January 2015.

[19] Ferrari, S. and Veltri, A.R. (2008) L'approccio esperienziale nell'offerta dei beni culturali. Il caso di "Emozioni da museo". Finanza Marketing e Produzione, 24, 66-95.

[20] Pine, B.J. and Gilmore, J.H. (1998) Welcome to the Experience Economy. Harvard Business Review, 76, 97-105. 
Submit or recommend next manuscript to SCIRP and we will provide best service for you:

Accepting pre-submission inquiries through Email, Facebook, LinkedIn, Twitter, etc. A wide selection of journals (inclusive of 9 subjects, more than 200 journals)

Providing 24-hour high-quality service

User-friendly online submission system

Fair and swift peer-review system

Efficient typesetting and proofreading procedure

Display of the result of downloads and visits, as well as the number of cited articles Maximum dissemination of your research work

Submit your manuscript at: http://papersubmission.scirp.org/

Or contact me@scirp.org 